Original Research Paper

\title{
Antifungal Potential of Leptadenia Hastata Against Some Pathogenic Fungi
}

\author{
${ }^{1}$ Isaac John Umaru, ${ }^{1}$ Fasihuddin A. Badruddin, ${ }^{1}$ Henry Y. Wakawa, \\ ${ }^{2}$ Hauwa A. Umaru and ${ }^{3}$ Kerenhappuch I Umaru \\ ${ }^{I}$ Faculty of Resource Science and Technology, \\ University of Malaysia Sarawak, Kuching, 94300, Kota Samarahan Malaysia \\ ${ }^{2}$ Department of Biochemistry Moddibo Adama University Yola, Adamawa State, Nigeria \\ ${ }^{3}$ Department of Biochemistry, University of Maiduguri, Borno State Nigeria
}

\author{
Article history \\ Received: 27-01-2018 \\ Revised: $26-02-2018$ \\ Accepted: 3-03-2018 \\ Corresponding Author: \\ Isaac John Umaru \\ Faculty of Resource Science \\ and Technology, University of \\ Malaysia Sarawak, Kuching, \\ 94300, Kota Samarahan \\ Malaysia \\ Email: umaruisaac@gmail.com
}

\begin{abstract}
The objective of this study was to evaluate if the plant extract could provide antifungal potential against some pathogenic fungi. Extract of Dichloromethane solvents was used for disc diffusion assay. The inhibitory concentration of the extract was performed by broth dilution method and zone of inhibition was studied by disc diffusion method at the concentration of $25,50,100,250,500$ and $1000 \mathrm{ppm}$ in DMSO. Fluconazole was used as the reference control for antifungal study. The extract showed maximum inhibition potential of zone of inhibition against most of the pathogen (Aspergillus niger, Aspergillus flavus, Candida tropicalis and Fusarium oxysporium) used at concentration $25 \mathrm{ppm}$ to $250 \mathrm{ppm}$ with zone of inhibition $(3.45 \pm 0,3.33 \pm 0.12,3.07 \pm 0.05$ and $2.97 \pm 0.10 \mathrm{~mm}$ respectively). The extract showed minimum inhibition potential against Fusarium oxysporium in all the concentration when compared with the control as well as to the other pathogens. Aspergillus niger and Aspergillus flavus was found to be more sensitive to Dichloromethane leaf extract followed by Candida tropical and lastly fusarium oxyspurium. The Present study indicates the potential usefulness of Dichloromethane leaf extract of Leptadenia hastata as antifungal agent.
\end{abstract}

Keywords: Aspergillus Niger, Aspergillus Flavus, Candida Tropicalis, Fusarium Oxysporium, Leptadenia Hastata, Fluconazole

\section{Introduction}

Leptadenia hastata (pers.) Decne belonging to family Asclepiadaceae is one of such medicinal plants, locally known as yadiya in Nigeria and Niger, hagalhadjar (Arabic) in Chad, hayla (Kusume) Ethiopia, ekamongo (Turkana) in Kenya, lolongo (Moore) in Burkina Faso, tarhat or darhat (Wolof), busumba amata (Jola) in Senegal and nzongnè (Bambara) in Mali. (Freiberger et al., 1998; Aberkane et al., 2002; Sena et al., 1998). It is an erect, ascending, shrub up to $1.5-3 \mathrm{~m}$ high with green stem and pale green alternating branches with watery sap. The plant is commonly used in traditional system of medicine for relieving pain and inflammation, as well as in a number of metabolic disorders such as diabetes and obesity.

The plant represents a rich source of antimicrobial agents. It is used medicinally in different countries and it is a source of many potent and powerful drugs. A wide range of medicinal plant parts extract are used as raw drugs and are said to possess varied medicinal properties. The different parts used include root, stembark and leaves. Some of these raw drugs are collected in small quantities by the local communities and folk healers for local use, many other raw drugs are collected in larger quantities and traded in the market as the raw material for many herbal industries (Ambikapathy et al., 2011).

Considering the vast potentiality of this plant Leptadenia hastata as sources for antimicrobial drugs with reference to antifungal agents. The present study was designed to evaluate the invitro anti-fungal potential of leave extract against four different fungal species, Aspergillus niger, Aspergillus flavin, Candida tropicalis and Fusarium oxysporium.

\section{Materials and Method}

Plants were collected from Michika Local Government Adamawa state Nigeria. Identification of plants was done through herbarium available in the Ahmadu bello University Zaria 


\section{Extract Preparation}

The leaves were washed with distilled water to remove the soil and dust particles, they were thoroughly air dried and powdered using laboratory grinder machine (FGR350, Quest Scientific) extraction using dichloromethane by placing $150 \mathrm{~g}$ of the powdered samples into an Erlenmeyer flask and dichloromethane three times the weight of the extracts was added, the solution was covered and shaken at an interval of an hour and then allowed at room temperature to stand for 7days, the mixture were then filtered using Whatman filter paper No.4 and the solvent was evaporated using a rotary evaporator (Heidolph Laborato 400) under reduced pressure below $50 \mathrm{EC}$. It was then stored under a frozen condition until required. $2 \mathrm{~g}$ of the extract was weighed and dissolved in $20 \mathrm{~mL}$ of Dimethyl sulfoxide (DMSO) to make a stock concentration of $100 \mathrm{mg} / \mathrm{ml}$ from which the various concentrations used were calculated. Fluconazole common name Diflucan (Pfizer Inc New York, NY) was used as reference standard for antifungal studies.

\section{Antifungal Potential}

The antifungal potential of the plant extract was performed by agar disc diffusion method. Dimethyl sulfoxide DMSO was used as a negative control and Fluconazole (Diflucan) was used as a positive control. The plates were incubated at $37^{\circ} \mathrm{C}$. The antimicrobial activity was taken on the basis of diameter of zone of inhibition in triplicate, which was measured before and after 5 days of incubation and the mean of three readings is presented. The presence of inhibition of the treated fungus was calculated using positive control as standard (100\% inhibition). (Cruickshank, 1975; Karwa et al., 1997; Aboh et al., 2014).

The plant extract and the standard antifungal agents were dissolved in DMSO, $100 \%$ biologically inert substances, with the disc diameter of $6 \mathrm{~mm}$. The extracts were separately dissolved in dimethyl sulphoxide. This (DMSO) solvent served as reference control for the antifungal study. The solvent control (DMSO) was also maintained throughout the experiment. Potato dextrose agar media was used for the antifungal study. The molten media was then inoculated with $200 \mu$ l of the inoculums $(1 \times 108 \mathrm{Cfu})$ and poured into the sterile Petri plates. The disc was saturated with $20 \mu \mathrm{l}$ of the extracts separately, allowed to dry and was introduced on the upper layer of the seeded agar plate. The plates were incubated at $28^{\circ} \mathrm{C}$ and the zone of inhibition was measured every after $24 \mathrm{~h}$ for five days.

\section{Fungal Preparation}

The fungi were standardized by inoculating sterile normal saline solution with a $48 \mathrm{~h}$ pure culture by adjustment of turbidity to match 0.5 McFarland standard.
Standardization of the microorganisms included harvesting fungal spores from a 7 days old culture on SDA slant. Ten milliliters of sterile normal saline containing 3\% w/v Tween 80 was used to disperse the spores with the aid of sterilized glass beads (Olowosulu et al., 2005) Standardization of the spore suspension to $1.0 \times 10^{6}$ spores $/ \mathrm{mL}$ was achieved with a UV spectrophotometer (Spectronic 20D; Milton Roy Company, Pacisa, Madrid, Spain) at $530 \mathrm{~nm}$ (OD at 530) of the suspensions and adjusted to a transmittance of $70-72 \%$. The plates were incubated at $37^{\circ} \mathrm{C}$ for $24 \mathrm{~h}$ (Aberkane et al., 2002).

\section{Statistical Analysis}

Values were expressed as Mean \pm standard deviation for three determinations of each experiment. The analysis was done using the software-SPSS one way ANOVA.

\section{Results and Discussion}

\section{Results}

The result as presented in Table 1 shows that the plant extract was effective in significantly reducing the growth of the pathogen as compared to the control drug. The dichloromethane extract of Leptadenia hastata inhibits the growth of Aspergillus niger, Aspergillus flavus, Candida tropicalis and Fusarium oxysporium in culture medium. The zone of inhibition is significant in all the solvent extract concentration and lower in 500, $1000 \mathrm{ppm}$. Aspergillus niger shows a higher inhibition compared to the control as well as at different treatment days at the same concentration on each fungus at 50 and $100 \mathrm{ppm}$, the zone of inhibition were $3.45 \pm 0.05$ and $3.55 \pm 0.05 \mathrm{~mm}$ and for 25,250 and $500 \mathrm{ppm}$ was $3.15 \pm 0.48,2.98 \pm 0.04$ and $2.38 \pm 0.10 \mathrm{~mm}$ respectively.

The growth of these fungi Aspergillus flavus was inhibited at the 5th day with zone of inhibition of $3.10 \pm 0.06 \mathrm{~mm}$ at $25 \mathrm{ppm}, 3.22 \pm 0.08 \mathrm{~mm}$, at $50 \mathrm{ppm}$ and $100 \mathrm{ppm}$ at $3.33 \pm 0.12 \mathrm{~mm}$, followed by $3.10 \pm 0.06 \mathrm{~mm}$ at $250 \mathrm{ppm}$. Table 1 shows the inhibitory effect on growth of these fungi these increases with the increase in days and concentrations of the extract.

Candida tropicalis, observation reveals that growth is more inhibited at the 5th day when compared with the others, at $25 \mathrm{ppm}$ the zone of inhibition was $2.98 \pm 0.08 \mathrm{~mm}, 50 \mathrm{ppm}$ it was $3.00 \pm 0.06 \mathrm{~mm}$, while at $100 \mathrm{ppm}$ it was $3.07 \pm 0.05 \mathrm{~mm}$ higher when compared to the different treatment days at the same concentration on each fungus as well as the control. However, inhibition increases with the increase in concentrations.

The growth of Fusarium oxysporium was observed to have been inhibited with increase in concentration too. The rate of inhibition at $25 \mathrm{pp}$ was $2.85 \pm 0.14,50 \mathrm{ppm}$ was $2.90 \pm 0.11 \mathrm{~mm}$, while $100 \mathrm{ppm}$ was observed to be the higest by $2.97 \pm 0.10 \mathrm{~mm}$. 
Table 1: Effect of dichloromethane leaf extract of Leptadenia hastata on Fungi

\begin{tabular}{|c|c|c|c|c|c|c|c|c|}
\hline \multirow[b]{2}{*}{ Organisms } & \multicolumn{8}{|c|}{ Concentration (ppm) } \\
\hline & Day & Control & 25 & 50 & 100 & 250 & 500 & 1000 \\
\hline \multirow[t]{5}{*}{ Aspergillus niger } & 1 & $0.86 \pm 0.05$ & $0.78 \pm 0.12$ & $0.80 \pm 0.09^{d}$ & $0.63 \pm 0.15$ & $0.95 \pm 0.05^{\text {bd }}$ & $0.47 \pm 0.12$ & $0.18 \pm 0.08$ \\
\hline & 2 & $1.24 \pm 0.08$ & $1.24 \pm 0.08$ & $1.63 \pm 0.08^{\mathbf{b}}$ & $1.52 \pm 0.10^{\mathrm{d}}$ & $1.60 \pm 0.14^{\mathrm{d}}$ & $0.80 \pm 0.08^{\mathrm{d}}$ & $0.45 \pm 0.10$ \\
\hline & 3 & $1.93 \pm 0.05$ & $1.65 \pm 0.08$ & $1.78 \pm 0.12$ & $1.75 \pm 0.05$ & $1.45 \pm 0.08$ & $0.75 \pm 0.10$ & $0.48 \pm 0.07$ \\
\hline & 4 & $3.06 \pm 0.13$ & $2.80 \pm 0.19$ & $2.73 \pm 0.08$ & $2.70 \pm 0.06$ & $2.50 \pm 0.06$ & $1.78 \pm 0.12$ & $0.88 \pm 0.08$ \\
\hline & 5 & $3.45 \pm 0.05$ & $3.15 \pm 0.48^{\text {ad }}$ & $3.45 \pm 0.05^{\mathrm{ad}}$ & $3.55 \pm 0.05^{\mathrm{abd}}$ & $2.98 \pm 0.04^{\mathrm{a}}$ & $2.38 \pm 0.10^{\mathrm{a}}$ & $1.85 \pm 0.05^{\mathrm{a}}$ \\
\hline \multirow[t]{5}{*}{ Aspergillus flavin } & 1 & $0.86 \pm 0.06$ & $0.48 \pm 0.16$ & $0.75 \pm 0.12$ & $0.70 \pm 0.00^{\mathbf{d}}$ & $0.52 \pm 0.15$ & $0.50 \pm 0.20^{\mathrm{d}}$ & $0.23 \pm 0.12$ \\
\hline & 2 & $1.80 \pm 0.15$ & $1.80 \pm 0.20^{\mathrm{d}}$ & $1.55 \pm 0.08$ & $1.32 \pm 0.08$ & $1.23 \pm 0.12$ & $0.75 \pm 0.05$ & $0.48 \pm 0.15$ \\
\hline & 3 & $2.10 \pm 0.09$ & $1.80 \pm 0.09$ & $1.73 \pm 0.10$ & $1.70 \pm 0.16$ & $1.42 \pm 0.31$ & $0.82 \pm 0.21$ & $0.37 \pm 0.14$ \\
\hline & 4 & $3.02 \pm 0.15$ & $2.88 \pm 0.12^{\mathrm{d}}$ & $2.87 \pm 0.15^{\mathrm{d}}$ & $2.87 \pm 0.05$ & $2.48 \pm 0.12$ & $2.18 \pm 0.15$ & $1.97 \pm 0.08^{\text {ad }}$ \\
\hline & 5 & $3.22 \pm 0.10$ & $3.10 \pm 0.06^{\mathrm{a}}$ & $3.22 \pm 0.08^{\mathrm{a}}$ & $3.33 \pm 0.12^{\mathrm{ab}}$ & $3.10 \pm 0.06^{\mathrm{ad}}$ & $2.90 \pm 0.09^{\text {ad }}$ & $1.85 \pm 0.10$ \\
\hline \multirow[t]{5}{*}{ Candida tropicalis } & 1 & $1.05 \pm 0.06$ & $1.27 \pm 0.37^{\text {bd }}$ & $0.53 \pm 0.12$ & $0.58 \pm 0.08$ & $0.47 \pm 0.10$ & $0.38 \pm 0.12$ & $0.25 \pm 0.16^{\mathrm{d}}$ \\
\hline & 2 & $1.85 \pm 0.06$ & $1.67 \pm 0.10$ & $1.73 \pm 0.08^{\mathrm{d}}$ & $1.30 \pm 0.09$ & $1.23 \pm 0.10$ & $0.78 \pm 0.08$ & $0.53 \pm 0.05^{\mathrm{d}}$ \\
\hline & 3 & $1.90 \pm 0.09$ & $1.93 \pm 0.08^{\mathrm{d}}$ & $2.02 \pm 0.14^{\mathrm{d}}$ & $2.13 \pm 0.10^{\mathrm{d}}$ & $2.20 \pm 0.13^{\mathrm{bd}}$ & $1.92 \pm 0.08$ & $1.80 \pm 0.18$ \\
\hline & 4 & $2.78 \pm 0.08$ & $2.53 \pm 0.08$ & $2.72 \pm 0.08$ & $2.83 \pm 0.08$ & $2.93 \pm 0.08^{\mathrm{abd}}$ & $2.28 \pm 0.21$ & $1.95 \pm 0.10^{\mathrm{a}}$ \\
\hline & 5 & $3.23 \pm 0.12$ & $2.98 \pm 0.08^{\mathrm{a}}$ & $3.00 \pm 0.06^{\mathrm{a}}$ & $3.07 \pm 0.05^{\mathrm{a}}$ & $2.92 \pm 0.08$ & $2.53 \pm 0.08^{\mathrm{a}}$ & $1.93 \pm 0.09^{\mathrm{d}}$ \\
\hline \multirow[t]{5}{*}{ Fusarium oxysporium } & 1 & $0.70 \pm 0.09$ & $0.45 \pm 0.16$ & $0.43 \pm 0.19$ & $0.57 \pm 0.12$ & $0.42 \pm 0.17$ & $0.37 \pm 0.16$ & $0.18 \pm 0.08$ \\
\hline & 2 & $1.60 \pm 0.09$ & $1.42 \pm 0.15$ & $1.53 \pm 0.12$ & $1.30 \pm 0.06$ & $1.08 \pm 0.08$ & $0.62 \pm 0.10$ & $0.42 \pm 0.16$ \\
\hline & 3 & $2.02 \pm 0.08$ & $1.93 \pm 0.10^{\mathrm{d}}$ & $2.02 \pm 0.08^{\mathrm{d}}$ & $2.07 \pm 0.14$ & $2.02 \pm 0.16^{\mathrm{d}}$ & $2.18 \pm 0.15^{\text {bd }}$ & $1.92 \pm 0.08^{\mathrm{d}}$ \\
\hline & 4 & $2.82 \pm 0.08$ & $2.50 \pm 0.14$ & $2.38 \pm 0.25$ & $2.72 \pm 0.15$ & $2.77 \pm 0.12^{\mathrm{a}}$ & $2.48 \pm 0.08^{\text {ad }}$ & $1.88 \pm 0.08^{\mathrm{a}}$ \\
\hline & 5 & $3.23 \pm 0.13$ & $2.85 \pm 0.14^{\mathrm{a}}$ & $2.90 \pm 0.11^{\mathrm{a}}$ & $2.97 \pm 0.10^{\mathrm{a}}$ & $2.62 \pm 0.08$ & $2.32 \pm 0.16$ & $1.43 \pm 0.12$ \\
\hline
\end{tabular}

Values are Mean \pm SD for six determinations

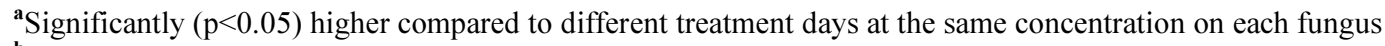

${ }^{\mathbf{b}}$ Significantly $(\mathrm{p}<0.05)$ higher compared to the control on each fungus in each row

${ }^{d}$ Significantly $(\mathrm{p}<0.05)$ higher compared to other fungi on the same day on each concentration

\section{Discussion}

The study revealed the antifungal activity of the extract against the tested species of microorganisms between concentration ranges for 25 to $1000 \mathrm{ppm}$. The results of this study revealed that the extracts possess antifungal activity in a concentration dependent manner against the test organisms and were comparable with the standard drug.

The inhibition yielded at concentration 25-250ppm was found to be active against all tested strains under study. However, the extract showed higher significant antifungal activity against Aspergillus flavus and Aspergillus niger over the other pathogens. Though the extract showed moderate activity at all concentration on the fungal species, the potency exhibited less significant activity against Candida tropicalis as well as Fusarium oxysporium strains. Thus, the antimicrobial activities of plant related have also been found registered in various literature (Satish et al., 2007; Bhardwaj, 2012., Gujar and Taknkar, 2012; Ilyas et al., 1997; Dubey and Kumar, 2003; Dubey et al., 2009) found almost similar effect of Leptadenia hastata dichloromethane extract on growth of some other fungi's.

The result of this study indicating that differential activities of the plant extracts on the growth of different fungi, because many of these extract concentration has shown significant and aggressively inhibition against the growth of some of this tested fungus.
The antifungal activities of this medicinal plants are attributed due to the presence of flavonoids and tannins. (Barnabas and Nagarajan, 1988). The presence of this metabolite in the leaf extract confirm its potential against the selected pathogens. This shown the significant and aggressive inhibition which was observed against the pathogen as it supressed the growth of all the pathogenic fungi. Thus, the potential usefulness of dichloromethane leaf extract of Leptadenia hastata in the treatment of various pathogenic diseases, as well as helping in the discovery of new chemical classes for antifungal drugs that could serve as selective agents for the maintenance of human health should be considered.

\section{Conclusion}

The outcome of this study supports the traditional medicine uses of different plant extract concentration in the treatment of different infections caused by pathogenic fungi, indicating the usefulness of dichloromethane leaf extract of Leptadenia hastata as antifungal agents.

\section{Acknowledgement}

The authors are thankful to ZAMALA and the Natural Product laboratory FRST/FSTS University Malaysia Sarawak for the enabling support to carry out this study. 


\section{Author's Contribution}

Isaac John Umaru: Design of experiment, data analysis, discussion and write of the manuscripts.

Fasihuddin A Badruddin: Coordinator for research, design research experiment and supervision of work.

Henry Y. Wakawa: Proof read of the manuscripts

Hauwa A. Umaru and Kerenhappuch I Umaru: Coordinator, Sample collection, preparation and data analysis.

\section{Ethics}

This article is original and contains unpublished material. The corresponding author confirms no conflict of interest and all other authors have read and approved the manuscript. No ethical issues involved.

\section{References}

Freiberger, C.E., D.J. Vandergagt, A. Pastuszyn, R.S. Glew and G. Mounkarla et al., 1998. Nutrient content of edible leaves of seven wild plants from Niger. Plant. Foods. Hum. Nutr, 53: 57-69.

Aberkane, A., M. Cuenca-Estrella, A. Gomez-Lopez, E. Petrikkou and E. Mellado et al., 2002. Comparative evaluation of two different methods of inoculum preparation for antifungal susceptibility testing of filamentous fungi. J. Antimicrob. Chemother, 50: 719-22.

Ambikapathy, V., S. Gomathi and A. Panneerselvam, 2011. Effect of antifungal activity of some medicinal plants against Pythium debaryanum (Hesse). Asian J. Plant Sci. Res., 1: 131-34

Barnabas, C.G and S. Nagarajan, 1988. Role of flavonoids and tannins in some medicinal plants: A review. Fitoterapia, 3: 508-510.

Bhardwaj, S.K., 2012. Evaluation of plant extracts as antifungal agents against Fusarium solani (Mart.) Sacc. World J. Agric. Sci., 8: 385-388.

Sena, L.P., D.J. Vanderjagt, C. Rivera, A.T. Tsin and I. Muhamada et al., 1998. Analysis of nutritional component of eight famine foods of the republic of Niger. Plant Foods Hum. Nutr., 52: 17- 30.
Cruickshank, R., 1975. The Practice of Medical Microbiology. 1st Edn., Churchill Livingstone, London, pp: 98.

Dubey, R.C. and R. Kumar. 2003. Efficacy of Azadirachtin of sclerotia of Macrophomina phaseolina causing charcoal rot in soybean. Indian Phytopathol., 56: 216-217.

Dubey, R.C., H. Kumar and R.R. Pandey, 2009. Fungi toxic effect of neem extract on growth and sclerotial survival of Macrophomina phaseolina In vitro. J. Am. Sci., 5: 17-24.

Gujar, J. and D. Talwankar, 2012. Antifungal potential of crude plant extract on some pathogenic fungi. World J. Sci. Technol., 2: 58-62.

Karwa, V.G., P.N. Sathawane, V.S. Kasture, S.B. Kasture and S.C. Pal, 1997. Evaluation of antifungal activity by agar disc diffusion method. Indian Drugs, 34: 174-176.

Olowosulu, A.K., Y.K.E. Ibrahim and P.G. Bhatia, 2005. Studies on the antimicrobial properties of formulated creams and ointments containing Baphia nitida heartwood extract. J. Pharm. Biores., 2: 124-130.

Aboh, M.I., B.O. Olayinka, G.O. Adeshina and P. Oladosu, 2014. Preliminary studies on the antifungal activities of the phyto compounds from Mitracarpus villosus (Sw.) Dc aerial parts obtained from Abuja, Nigeria. Mal. J. Microbiol., 10: 133-138.

Ilyas, M.B., K. Iftikar, W. Anwar and M. Haq, 1997. Effect of different neem products on the vegetative growth and sclerotial production of Macrophomina phaseolina. Pak. J. Phytopathol., 9: 77-79.

Satish, S., D.C. Mohana, M.P. Ranhavendra and K.A. Raveesha, 2007. Antifungal activity of some plant extracts against important seed borne pathogens of Aspergillus sp. J. Agric. Technol., 3: 109-119. 